International Journal of Current Advanced Research

ISSN: O: 2319-6475, ISSN: P: 2319 - 6505, Impact Factor: SJIF: 5.995

Available Online at www.journalijcar.org

Volume 6; Issue 3; March 2017; Page No. 2951-2953

DOI: http://dx.doi.org/10.24327/ijcar.2017.2953.0151

Research Article

\title{
KNOWLEDGE AND ATTITUDE ON SURGICAL PROCEDURES IN MANAGEMENT OF CLEFT PALATE
}

\section{Sindhu Priya Kuppusamy and Dhanraj M}

Saveetha dental college

\section{A R T I C L E I N F O}

\section{Article History:}

Received $17^{\text {th }}$ December, 2016

Received in revised form $18^{\text {th }}$ January, 2017

Accepted $12^{\text {th }}$ February, 2017

Published online $28^{\text {th }}$ March, 2017

\section{Key words:}

Knowledge, Attitude, Management of cleft palate

\begin{abstract}
A B S T R A C T
Background : The birth defect, and lack of tissue joining during development, leads to cleft palate and lip. Treating facial clefts is a highly challenging reconstructive problem in rhinoplasty. There are several surgical procedures and evaluations but these do not offer the ideal and standard procedure for surgeons. A questionnaire was performed to suggest the best surgical procedures from dentists, to treat the patients.

Aim : The purpose of this questionnaire, is to spread the knowledge about the treatment of cleft palate and at the same time indicates the corrections if the primary surgery failed.

Method : A questionnaire was taken from100 dental post graduate studentsin 1 month. A questionnaire with 10 questions was set to assess the knowledge about cleft palate.

Results : They believed that the main reason for development of cleft palate is genetic with a percentage of $36.6 \%$. The failure of cleft palate is $57.3 \%$ and it is caused by a secondary procedure. The most commonly seen cleft palate is cleft of soft palate only, with $40.8 \%$ chance. The routine repair of cleft palate does not come with repair of nose also. The desired method for cleft palate is hard and soft palate as a single procedure. The type of method used to identity cleft palate during pregnancy is by ultrasonography.

Conclusion : The purpose of this study was to provide administrations to patients, staff improvement, and the ideal utilisation of constrained assets and experts. We trust that the discoveries in this review will give preparatory data to possibly accomplish a standardised reason to invite more queries for more knowledge regarding cleft palate.
\end{abstract}

Copyright $\odot 2017$ Sindhu Priya Kuppusamy and Dhanraj M. This is an open access article distributed under the Creative Commons Attribution License, which permits unrestricted use, distribution, and reproduction in any medium, provided the original work is properly cited.

\section{INTRODUCTION}

Cleft palate is the most commonest congenital deformity. The incidence of cleft lip is 1 in 1000 live births in USA ${ }^{[1]}$. But cleft palate is 3 per 1000 live births and Cleft palate occurrence is more common in females than males ${ }^{[2]}$

The birth rate of clefts in Indiawas found out to be 1.09 of every 1000 births. A study found that $65 \%$ of children born with clefts were males.

Any surgical procedures for correction should be performed within the first year of age, mainly between 3-6 months, before speech development ${ }^{[3]}$. The purpose of this surgery is to restore all the tissues, and reposition the nasal septumto separate the nasal and oral cavity. The major role is to restore valve function. If the primary surgery fails, the nasal deformity along with the cleft palate becomes a more complicated surgery to correct ${ }^{[2]}$ The different procedures used were von Langenbeck, palatial pushback and doubleopposing z-plasty.

\section{*Corresponding author: Sindhu Priya Kuppusamy} Saveetha dental college
If the surgery is not performed there are two problems that occur, one is the difficulty in breathing and impaired nasal function and the other problem is the aesthetic look. Both can plunge the patient into negative life and put a social burden on them [4] Nasal deformities are mainly characterised by depressed nasal tip, shortened columella and dislocation of alar cartilage ${ }^{[5]}$. In a study conducted in the university of Szeged, their aim was to standardise the secondary rhinoplasty. To evaluate for the result of the primary surgery, a follow-up study was done ${ }^{[6]}$. Despite of surgical advances and their benefits of treating at young age, patients are usually affected by psychological conditions due to their condition. The importance of testing the after affects of a surgery including the psychological aspects is important to complete the experience. Self-esteem is influenced by the way people interact with individuals with cleft palate. People with low self-esteem usually are considered less intelligent and therefore participate less in social activities ${ }^{[5]}$.

Therefore to treat patients with cleft palate, a group of multispeciality professionals, including maxilla facial surgeons, plastic surgeons, speech therapists, dentists, and psychologists. 
This allows to achieve the best possible outcome for patient and family. The perception and vulnerability of the patients actions and their social behaviour and the impact the society has in them depends on their previous awareness and knowledge of the condition ${ }^{[6]}$. Parents knowledge about the condition can help to promote better understanding both by the parents and the affected child.

\section{MATERIALS AND METHODS}

This is a cross-sectional study conducted among 100 dental students in Saveetha dental college. The questionnaire contained 10 questions that were purposely selected for obtaining the knowledge and attitude about cleft palate and its causes and surgeries. The students were asked about general information regarding left palate, for example; the reason for development of cleft palate, preferred procedures, the number of cases approved each year.

\section{RESULTS}

With this standard questionnaire we could conclude that the individuals are fairly knowledgable on this topic. They believed that the main reason for development of cleft palate is genetic with a percentage of $36.6 \%$. The failure of cleft palate is $57.3 \%$ and it is caused by a secondary procedure. The most commonly seen cleft palate is cleft of soft palate only, with $40.8 \%$ chance. There is $28.3 \%$ chance that Cleft palate management was highly considered by dentists and surgeons the most. The most attained surgery is cleft palate repair with a 46.2\%. The most common age groups participating are between 6 months to 1 year by $39.8 \%$. The preferred procedure of cleft palate is double - opposing $\mathrm{z}$ plasty with $38.5 \%$. The routine repair of cleft palate does not come with repair of nose also. The desired method for cleft palate is hard and soft palate as a single procedure. The type of method used to identity cleft palate during pregnancy is by ultrasonography.

\section{DISCUSSION}

CLP is preventable to some degree, and its surgical amendment can to a great extent accomplish to normality and decent quality of life. Subsequently, satisfactory knowledge and awareness about the causes, treatment and aversion of CLP may counter the negative convictions and states of mind toward and even decrease the occurrence of cleft ${ }^{[7]}$. Guardians' learning about the CLP may advance better wellbeing related with the conduct of their children. If the child gets the sufficient surgery before the first year of age, generally there is no requirement for auxiliary rhinoplasty. In each other case auxiliary septa-rhinoplasty is prompted ideally after the puberty age however not before the age of 16 .

There is as of now a substantial variety in the planning of parted surgery and the surgical systems that are utilised. In the present report, a lion's share of children with congenital fissure experience repairs somewhere around 10 and 12 weeks of age, perhaps because of wellbeing and the presence of acceptable lip tissue connected with this later intervention ${ }^{[8]}$. Most of the respondents have heard and seen CLP, which is not surprise, since it was taken in a big college that have a high treatment facility for CLP. Be that as it may, most respondents did not know the cause, the suitable time of treatment and whether CLP could be averted. Likewise, noteworthy knowledge was seen in alternate things used to test information, for example about the failure of cleft palate that it was believed to be due to the corrective procedure ${ }^{[9]}$. The most common procedure to be attained by the hospitals is cleft palate repair. Poor information about CLP has been accounted for in numerous provincial and urban Asian and African populations. Absence of information of accessibility of repair is the most widely recognised reason for late presentation in Nepal ${ }^{[10]}$. Cultural and religious components influence discernments and knowledge with many crediting the cause to superstitious convictions.

We selected 10 items of the questionnaire to test knowledge in an attempt to obtain a more accurate level of knowledge. Studies that have reported a higher level of awareness have not comprehensively assessed knowledge. This study demonstrated that variations exist between the level of awareness and knowledge. We opined that using scored multiple items to test knowledge gives a more accurate index of knowledge.Children with CLP usually suffer from having low self-esteem, speech difficulty, anxiety and depressive symptoms. The physical appearance gave off an impression of being a noteworthy issue, as indicated by Bernstein et al ${ }^{[11][12]}$. This finding is not steady with the result of Millard's study, probably because of the distinction in patient age between the reviews. As indicated by Bernstein and Kapp, and Belfer et $a l^{[13]}$, these patients will require extra surgical treatment to enhance their physical appearance. Physical issues appear to emphatically correspond with social difficulties; the present review affirmed that CLP patients are harassed more much of the time than their associates, which has additionally been accounted for by Hunt et al ${ }^{[14][15]}$.

\section{CONCLUSION}

The purpose of this study was to provide administrations to patients, staff improvement, and the ideal utilisation of constrained assets and experts. Contributes greater knowledge and assessment to children and improves their well-being and satisfaction in regard to their society.

This study has showed that there are variations in the knowledge perceived by different dental students. One half of the individuals have a fair knowledge on this topic while the other half are lacking the knowledge and maybe they need extra seminars, lectures and conferences to be updated on the recent advances. We trust that the discoveries in this review will give preparatory data to possibly accomplish a standardised reason to invite more queries and provide an open ground for more knowledge regarding cleft palate.

\section{Reference}

1. Mossey PA, Modell B. Epidemiology of oral clefts 2012: an international perspective. Front Oral Biol. 2012;16:1-18

2. Mars M, Sell D, Habel A. Management of Cleft Lip and Palate in the Developing World. Chichester: John Wiley \& Sons, Ltd.; 2008.

3. Hubli EH, Noordhoff MS. Smile train: changing the world one smile at a time. Ann PlastSurg. 2013;71:45

4. Rai SM, Nakarmi K, Basnet S, et al. Age of individuals undergoing cleft lip and cleft palate surgeries in Nepal. 
5. Mulliken JB. The changing faces of children with cleft lip and palate. N Engl J Med. 2004;351:745-747.

6. Sommerlad BC. Management of Cleft Lip and Palate in the Developing World. Chichester, UK: John Wiley \& Sons Ltd; 2008.

7. NolstTrenite GJ. Secondary surgery of the cleft-lip nose. In: NolstTrenité GJ, editor. Rhinoplasty. Amsterdam: Kugler Publications; 1993. pp. 105-116

8. Nakamura N, Sasaguri M, Okawachi T, Nishihara K, Nozoe E. Secondary correction of bilateral cleft lip nose deformity - Clinical and three-dimensional observations on pre- and postoperative outcome. $J$ CraniomaxillofacSurg. 2011;39(5):305-12. doi: 10.1016/j.jcms.2010.05.008.

9. Millard T, Richman C.. Different cleft conditions, facial appearance, and speech: relationship to psychological variables. Cleft Palate Craniofac $J$ 2001; 38: 68-75
10. Klassen AF, Tsangaris E, Forrest CR, et al. Quality ofLife of children treated for cleft lip and/or palate: a systematic review. J PlastReconstrAesthetSurg 2012; 65: 547-557

11. Turner SR, Thomas PW, Dowell $\mathrm{T}$, et al. Psychological outcomes amongst cleft patients and their families. Br J PlastSurg 1997; 50: 1-9

12. Richman LC, Eliason MJ.. Development in children with cleft lip and/or palate: intellectual, cognitive, personality, and parental factors. Semin Speech Lang 1986; 7: 225-239

13. Kapp-Simon KA, Simon DJ, Kristovich S.. Selfperception, social skills, adjustment, and inhibition in young adolescents with craniofacial anomalies. Cleft Palate Craniofac J 1992; 29: 352- 356

14. Kapp-Simon KA.. Self-concept of primary-school-age children with cleft lip, cleft palate, or both. Cleft Palate J 1986; 23: 24- 27

15. Rumsey N, Bull R.. The effects of facial disfigurement on social interaction. Hum Learn $J$ Pract Res Appl 1986; 5: 203- 208

\section{Please cite this article in press as:}

Sindhu Priya Kuppusamy and Dhanraj M (2017), 'Knowledge and attitude on surgical procedures in management of cleft palate', International Journal of Current Advanced Research, 6(3), pp. 2951-2953.

http://dx.doi.org/10.24327/ijcar.2017. 2953.0151 